\title{
Managing pediatric hepatitis C: current and emerging treatment options
}

This article was published in the following Dove Press journal:

Therapeutics and Clinical Risk Management

13 August 2009

Number of times this article has been viewed

\author{
Wikrom Karnsakul \\ Mary Kay Alford \\ Kathleen B Schwarz \\ Pediatric Liver Center, Division \\ of Pediatric Gastroenterology \\ and Nutrition, Johns Hopkins School \\ of Medicine, Baltimore, MD, USA
}

\begin{abstract}
Since 1992, the maternal-fetal route of transmission has become the dominant route for acquisition of hepatitis $\mathrm{C}(\mathrm{HCV})$ infection by children. With increasing knowledge of antiviral treatment for $\mathrm{HCV}$ infection, the main goal of therapy is to achieve a sustained virological response (SVR) as defined by undetectable serum HCV RNA by polymerase chain reaction assay six months after cessation of therapy. In young children, interferon therapy is more effective than in adults with chronic HCV infection (CHC). Although children clearly have a milder degree of liver pathology, data have indicated that hepatic inflammation from $\mathrm{HCV}$ infection can progress to fibrosis or cirrhosis in children. Hepatocellular carcinoma has been reported in adolescents with CHC. In this article, recent improvements in therapy of children with $\mathrm{CHC}$ and in the clinical development of new emerging drugs with potential use in children will be reviewed.
\end{abstract}

Keywords: chronic hepatitis C, children, current therapy, pegylated interferon

\section{Introduction}

Hepatitis C virus (HCV) was first discovered in 1989 and ever since, HCV infection has become a global public health problem. The prevalence of HCV varies in different parts of the world. ${ }^{1,2}$ It is estimated that 170 million people worldwide have been or are infected with HCV. There are approximately seven million adults and 100,000 children infected with chronic HCV (CHC) in the United States. ${ }^{3}$ Although transfusion-transmitted $\mathrm{HCV}$ was the major form of $\mathrm{HCV}$ in the pediatric age group when the virus was first described, ${ }^{4,5}$ since 1992 , when the majority of blood units transfused have been free of $\mathrm{HCV}$ (estimated to be $0.01 \%-0.001 \%$ per transfusion, ${ }^{4-6}$ the maternal-fetal route of transmission of this virus has become the dominant route for new cases of $\mathrm{HCV}$.

The main goal of therapy in HCV infection is to achieve a sustained virologic response (SVR; Table 1). Late relapse is rare after SVR. Virologic data indicate the durability of undetectable virus from serum in almost all cases $(>99 \%)$ after SVR. ${ }^{7}$ This goal is practically equivalent with eradication of $\mathrm{HCV}$ infection and cure of the underlying HCV-induced liver disease. ${ }^{8}$ Since 2005, the current standard in HCV treatment in adults consists of combination regimens of pegylated interferon- $\alpha$ (pegIFN- $\alpha$ ) with ribavirin $(\mathrm{RBV})$. However, this treatment is associated with several and sometimes severe adverse effects, limiting the efficacy and applicability in an appreciable number of patients with CHC-induced liver disease. ${ }^{9}$ The treatment is relatively contraindicated in end-stage liver and renal disease. Therefore, the need for improvement of existing 
Table I Terminology for virologic response commonly used in predicting the outcome of hepatitis C virus (HCV) treatment ${ }^{10}$

\begin{tabular}{|c|c|}
\hline Terminology & Definition \\
\hline Sustained virologic response (SVR) & $\begin{array}{l}\text { Undetectable serum HCV-RNA determined with the most sensitive polymerase } \\
\text { chain reaction (PCR) technique } 24 \text { weeks after the end of treatment (ETR) }\end{array}$ \\
\hline Rapid virologic response (RVR) & Undetectable serum HCV RNA $(<50 \mathrm{IU} / \mathrm{ml})$ by treatment Week 4 \\
\hline Early virologic response (EVR) & $\begin{array}{l}\geq 2 \log _{10} \mathrm{IU} / \mathrm{mL}(100 \text {-fold) decline in serum HCV RNA from pretreatment baseline } \\
\text { or undetectable serum HCV RNA by treatment Week } 12\end{array}$ \\
\hline Partial virologic response & $\begin{array}{l}\geq 2 \log _{10} \mathrm{IU} / \mathrm{mL}(100 \text {-fold) decline in serum HCV RNA from pretreatment baseline } \\
\text { at treatment Week } 12 \text { but serum HCV RNA still detectable at treatment Week } 24\end{array}$ \\
\hline Null response & $\begin{array}{l}<2 \log _{10} 1 \mathrm{U} / \mathrm{mL}(100 \text {-fold }) \text { decline in serum If HCV RNA from pretreatment } \\
\text { baseline } 12 \text { weeks after treatment was initiated }\end{array}$ \\
\hline Virologic breakthrough & $\begin{array}{l}\text { Reappearance of serum HCV RNA during treatment after initially becoming } \\
\text { undetectable HCV RNA }\end{array}$ \\
\hline Relapse & $\begin{array}{l}\text { Reappearance of serum HCV RNA after the treatment were discontinued in a } \\
\text { patient who achieved and maintained undetectable HCV RNA throughout the } \\
\text { duration of treatment }\end{array}$ \\
\hline
\end{tabular}

therapies and for development of new effective, safe, and tolerable drugs is a matter of great clinical relevance and importance. Although there are a number of potentially new drugs currently being tested in adults which appear to more effective than the current therapy, these will need careful study in the pediatric population before general use.

\section{Development in HCV therapy and ongoing clinical drug trials in adults}

In several clinical trials, the response to treatment can be categorized as biochemical, virologic, or histologic. Quantitative assessment of paired liver biopsy pre- and post-treatment has been standardized. ${ }^{8}$ As the efficacy of HCV treatment has improved, terminology for virologic response is commonly used in predicting and comparing the outcome of HCV treatment (Table 1). ${ }^{10}$

Type 1 IFNs are natural cellular proteins with variable actions such as inhibition of HCV replication, induction of cytokine secretion, recruitment of immune effector cells, and induction of cell differentiation. IFN was the only treatment option until the mid-1990s. IFN-based treatments were different types and regimen but in general resulted in $15 \%-20 \%$ SVR. ${ }^{11} \mathrm{RBV}$ is a purine nucleoside analogue that works by inhibiting host enzyme inosine monophosphate dehydrogenase (IMPDH) and HCV polymerase, thereby inhibiting replication of the viral genome, RNA virus mutagenesis, and improving $\mathrm{T}$-cell functions and response to HCV infection. ${ }^{12}$ RBV was approved to be used in combination therapy since 1998 as RBV monotherapy did not result in impressive SVR. ${ }^{13}$ Combination therapy with IFN and RBV augmented the SVR to $35 \%-40 \%$ and by late 1998 , randomized placebo-controlled trials in the therapy proved of superior efficacy in treatment-naïve CHC patients with 24 or 48 weeks of combination therapy, with an SVR of $31 \%$ and $43 \%$, respectively compared to IFN monotherapy with a SVR of $18 \%{ }^{14-16}$ Improved SVR with combination therapy was also observed in those with advanced fibrosis and cirrhosis who failed IFN monotherapy. ${ }^{17}$ SVR increased from $29 \%$ to $38 \%$ when combination therapy was prolonged from 24 to 48 weeks, respectively. Hepatocellular carcinoma (HCC) markedly decreased among those with an SVR. ${ }^{18,19}$ Favorable parameters for combination therapy are similar to that for IFN monotherapy including genotype 2 and 3, low viral load with serum HCV-RNA $<2$ million copies/mL, age less than 40 years, minimal fibrosis on biopsy and female gender. ${ }^{20}$

PegIFN is a recombinant IFN- $\alpha$ either $2 a$ or $2 b$, covalently bound to polyethylene glycol (PEG) to standard IFN and does not alter the pharmacodynamics or safety/tolerability profiles of IFN- $\alpha .{ }^{21}$ It reduces the difference between serum peaks and troughs and prolongs its half-life. PEG molecule in PegIFN- $\alpha 2 \mathrm{a}$ is a branched $40-\mathrm{kD}$ molecule with elimination half-life of 80 hours, while that in PegIFN- $\alpha 2 b$ is a linear $12-\mathrm{kD}$ molecule with elimination half-life of 40 hours. No significant differences were noted between the two pegIFN molecules plus RBV in terms of SVR. ${ }^{22}$ PegIFN/RBV is the mainstay of HCV therapy and patients with genotype 1 infection receiving a combination therapy of pegIFN/RBV have the SVR rate of $40 \%$ to $55 \%$ vs $70 \%$ to $90 \%$ among those with genotype 2 or 3 infection. ${ }^{23}$ Long-term benefits include decreased morbidity and mortality, including decreased rates of HCC and improved quality of life for the patients and family. ${ }^{24}$ More data from randomized control trials indicated that some genotype 2 and 3 patients are undertreated, with one guideline recommending the therapy 
for 24 weeks in patients with these genotypes. ${ }^{20}$ Patients with genotype 1 or 4 require 48 weeks of treatment. ${ }^{20}$ In future, treatment guidelines will require further studies evaluating other independent viral and host factors which affect the predictive value of early virologic response (EVR) and rapid virologic response (RVR). ${ }^{7}$

Patients with $\mathrm{CHC}$ who fail to respond to initial therapy with pegIFN and RBV are still at risk for developing progression of their liver disease, but retreatment with pegIFN/RBV yields low SVR rates $(<10 \%) .{ }^{6}$ Long-term IFN has been considered for patients who failed previous antiviral therapies. ${ }^{25}$ Albuferon (albumin-interferon alpha 2b), a recombinant single polypeptide molecule coded by the fusion of the human serum albumin and the IFN- $\alpha$ genes, can be dosed once every two weeks or even once every four weeks. ${ }^{26}$ A wholly synthetic IFN alfacon-1 or consensus IFN (CIFN), ${ }^{27-29}$ a recombinant type 1 IFN derived by scanning the sequences of several natural alpha IFNs, displays 5-10 times higher biological activity than conventional IFN. However, it appears unlikely that Albuferon or CIFN will replace pegIFN and RBV, unless a clear advantage over them in effectiveness or side effects is demonstrated in the ongoing or future studies. ${ }^{6,30}$

Specifically targeted antiviral therapy for $\mathrm{HCV}$ has been developed based on the molecular structure of HCV, its component proteins, and the various phases of the replication cycle of the virus. HCV antiviral development involves all three of classes, HCV protease inhibitors (PIs), nucleoside $\mathrm{HCV}$ polymerase inhibitors (NIs), and nonnucleoside $\mathrm{HCV}$ polymerase inhibitors (NNIs). Only two direct-acting HCV inhibitors entered phase III trials in 2008, both of which are PIs (telaprevir and boceprevir). ${ }^{31}$ The success of HIV antiviral therapy gave hope that $\mathrm{HCV}$ NS3-4A protease could be an excellent target for a structural-base design approach. When telaprevir was added to baseline regimens of pegIFN- $\alpha 2 \mathrm{a}$ in group 1 (telaprevir with pegIFN- $\alpha 2 \mathrm{a} / \mathrm{RBV}$ for 12 weeks followed by pegIFN- $\alpha 2 \mathrm{a} / \mathrm{RBV}$ alone for 12 weeks) and compared to group 2 (telaprevir with pegIFN- $\alpha 2 \mathrm{a}$ / RBV for 12 weeks), the antiviral efficacy improved over group 3 (telaprevir with pegIFN- $\alpha 2$ a for 12 weeks) or group 4 (pegIFN- $\alpha 2$ a alone for 48 weeks) with SVRs of $69 \%, 60 \%$, $36 \%$, and $46 \%$, respectively. ${ }^{32}$ This result suggests that RBV is important for improving SVR with telaprevir/pegIFN treatment. The HCV-RNA-dependent RNA polymerase (HCV Pol) can be inhibited either by nucleoside/nucleotide analogues or by nonnucleoside analogue molecules. The NS5b-encoded HCV Pol is an RNA-dependent RNA polymerase that has two types of binding sites available for inhibitors of HCV Pol inhibitors.
NIs bind in the HCV Pol catalytic (active) site and NNIs can bind four (or more) other sites on HCV Pol located outside the active site. ${ }^{31}$ Currently several agents are under development on phase I and II trials, whereas some were withdrawn because of safety concerns. ${ }^{20}$

Taribavirin hydrochloride, a liver-targeting prodrug for $\mathrm{RBV}$, preferentially releases RBV at the level of the hepatocyte and does not significantly accumulate in erythrocytes. However it has not achieved comparable rates of efficacy with less hemolysis. ${ }^{33}$ Antisense oligonucleotide molecules, ribozymes, or small interfering RNAs (siRNAs) can interrupt the internal ribosome entry site (IRES) region of HCV RNA binding of the $40 \mathrm{~S}$ ribosomal subunit and result in conformational changes in the ribosome disrupting the viral life-cycle of the virus by cleaving the RNA genome. ${ }^{20,34}$ The development of some of these agents is still in an early phase, limited to laboratory cell lines. The development of others has been interrupted because of adverse effects and limited efficacy. ${ }^{34}$

Among the most promising therapeutic agents in development are the agonists of the Toll-like receptors (TLR). TLR are pathogen recognition molecules expressed on immunologic cells that sense the presence of invading microorganisms and initiate the innate immune response or acute inflammation. Stimulation of the appropriate TLR may induce and restore a potent innate and adaptive immune response which is usually dysfunctional in patients with CHC. ${ }^{20,35}$ To date, drugs that have an agonistic action with the TLR9 (CPG 10101 or Actilon) and TLR7 (ANA245 or Isatoribine) mimicking their function are under development for therapy of $\mathrm{HCV}$ infection. ${ }^{20,35}$

Increased rates of hepatocyte apoptosis and activated caspases have been observed in $\mathrm{CHC}^{36}$ Antifibrotic agents such as angiotensin receptor blockers and drugs regulating apoptosis pathways have been used in patients with $\mathrm{CHC}$ with compensated cirrhosis. ${ }^{37}$ Inhibiting caspases with a specific pancaspase inhibitor may play an important role in $\mathrm{HCV}$ treatment and cirrhosis in the future. IDN-6556, a potent inhibitor of caspases, the proteases that execute apoptosis lowered serum aminotransferase activity in a small number of patients with liver impairment in a prior phase I study, yet requires longer duration studies. ${ }^{38}$ When patients decompensate, orthotopic liver transplantation (OLT) is considered. The outcome of OLT in adults with $\mathrm{CHC}$ has been suboptimal and is limited by almost universal recurrent infection. ${ }^{39}$

\section{Current pediatric data}

The estimated prevalence of HCV antibody in children and adolescents aged up to 14 years was $0.2 \%$ to $0.4 \%$ in 
the National Health and Nutrition Examination Survey III population-based survey with approximately 100,000 children infected with $\mathrm{CHC}$ in the United States. ${ }^{3,40}$ The prevalence of anti-HCV antibody in pregnant women is $0.1 \%-2.4 \%$. Transmission rates are $4 \%-7 \%$ when the mother is viremic and mothers with $\mathrm{HCV}$ RNA $>10^{6}$ copies per $\mathrm{mL}$ are more likely to transmit the infection to the fetus compared to mothers with lower levels of viremia. ${ }^{41}$ Co-infection with the HIV virus increases the risk of transmission 4-5-fold but highly active retroviral therapy may significantly decrease this risk. ${ }^{42}$ The rate of viral clearance rates in children with $\mathrm{CHC}$ was $8 \%$ in a large prospective 10 year study; most of the children who cleared HCV did so in the first five years of follow-up. ${ }^{43,44}$ The significance of HCV RNA levels in long-term clinical outcomes of children with $\mathrm{CHC}$ is not well understood. A long-term follow-up study of 42 children with $\mathrm{CHC}$ demonstrated that children with an HCV RNA level below $4.5 \times 10(4) \mathrm{IU} / \mathrm{mL}$ at enrollment have a higher spontaneous viral clearance rate. ${ }^{44}$

Although the natural course of $\mathrm{CHC}$ in children is thought to be insidious over more than $10-15$ years, ${ }^{45,46}$ 121 treatment-naïve children in the PEDS-C trial demonstrated the presence of inflammation, fibrosis, and steatosis in liver biopsies taken at the beginning of the trial. ${ }^{40}$ However the degree of abnormality was milder than that reported for treatment-naïve adults with $\mathrm{CHC}$. The positive correlation of inflammation with duration of infection and fibrosis and of obesity with fibrosis suggest that children with $\mathrm{CHC}$ will be at risk for progressive liver disease as they age and possibly acquire other comorbid risk factors. ${ }^{40}$ Since the majority of children with $\mathrm{CHC}$ contracted $\mathrm{HCV}$ via maternal-to-fetal acquisition, they may develop chronic liver disease and its complication in the second or third decade. ${ }^{47} \mathrm{HCC}$ was reported in two young adolescents with $\mathrm{CHC}{ }^{3}$ Although Rodrigue and colleagues found that children with $\mathrm{HCV}$ infection in in the PEDS-C trial did not have global impairment in cognitive, behavioral, and emotional function at entry into the study, the authors did find higher caregiver stress and strain on the family system. ${ }^{48}$ All these factors along with the safety and efficacy of medications should play a role in decision-making for the therapy in children with $\mathrm{CHC}$.

The European Paediatric Hepatitis C Virus Network reported the natural history of 266 children with vertical HCV infection; approximately $20 \%$ appeared to clear the infection, $50 \%$ had evidence of chronic asymptomatic infection, and $30 \%$ had evidence of chronic active infection. ${ }^{49}$ Children with transfusion-acquired $\mathrm{HCV}$ also tend to have mild asymptomatic infection although rarely may proceed to decompensated liver disease and liver transplantation. ${ }^{50}$ In another large pediatric natural history study, $1.8 \%$ of children progressed to decompensated cirrhosis (mean age 9.6 years). These children were mostly perinatally infected with genotype 1a and most of the mothers were intravenous drug users. ${ }^{43}$

Diagnosis is usually made by screening of high-risk children for anti-HCV antibody. Infection is confirmed by HCV RNA by polymerase chain reaction (PCR) assay. The American Academy of Pediatrics recommends that infants born to HCV-infected mothers be screened by anti-HCV at 18 months post-partum, since passively acquired maternal antibody can persist for up to 18 months. ${ }^{51}$ In clinical practice, children with positive anti-HCV could potentially be lost to follow-up before 18 months as a result of social and compliance issues. For this reason, the PCR assays for HCV RNA could be helpful for early identification of these infants with $\mathrm{HCV}$ infection and provide adequate follow-up and proper education to the family.

Although in early 2000 no therapeutic regimen had received United States Food and Drug Administration (FDA) approval for treating children with $\mathrm{CHC}$, there have been already a number of pediatric IFN- $\alpha$ trials and 20 published manuscripts of the use of IFN monotherapy in children with CHC. Of the 19 trials, 366 treated and 105 untreated children were observed; five countries were represented. ${ }^{52}$ Average ETR was 54\% (0\%-91\%) and the average SVR was 36\% $(0 \%-73 \%)$. The SVR in children with genotype 1 was $27 \%$ vs $70 \%$ for nongenotype 1 . Five of 105 (5\%) untreated controls exhibited spontaneous viral clearance. Therefore IFN- $\alpha$ monotherapy was not generally recommended in children with CHC genotype 1 given the poor result. IFN- $\alpha 2 b$ at a dose of 3 or $5 \mathrm{MU} / \mathrm{m}^{2}$ three times weekly in combination with oral $\mathrm{RBV}(15 \mathrm{mg} / \mathrm{kg} / \mathrm{d})$ for 12 months proved to be effective in the treatment of $\mathrm{CHC}$ in children and adolescents for both vertically infected patients and for individuals with pre-treatment normal or elevated serum aminotransferase levels. The SVR was $61 \% .{ }^{53}$ The improved disease outcome and compliance to therapy with weekly pegIFN in adult HCV patients and small pilot studies in children with $\mathrm{CHC}$ suggested that the therapy may also improve antiviral efficacy in children. The ideal trial would be large scale, prospective, and controlled, and would include HCV genotype and viral load, histology, quality of life measures, and systematic recording of adverse events and of effects of therapy on growth and development.

The pharmacokinetics, efficacy and safety of pegylated interferon alpha2a (pegIFN- $\alpha 2 \mathrm{a})(40 \mathrm{kd})$ were first investigated in 14 children aged 2 to 8 years with CHC (13 genotype 1 , 1 non-1 genotype). ${ }^{54}$ The drug dose was calculated from each 
patient's body surface area (BSA) according to the formula $\operatorname{BSA}\left(\mathrm{m}^{2}\right) /\left(1.73 \mathrm{~m}^{2}\right) \times 180 \mu \mathrm{g}$, and patients were administered once-weekly subcutaneous injections for 48 weeks. At week 24, the mean trough concentration was about $20 \%$ below values obtained from adults treated with pegIFN-alpha2a, but the area under the curve from 0 to 168 hours was about $20 \%$ above adult values, suggesting that drug doses calculated from BSA achieved therapeutically adequate concentrations. All infected with genotype 1 achieved an SVR of $46 \%$ and the patients seemed to tolerate pegIFN well. ${ }^{54}$

A combination treatment of weekly pegIFN $\alpha-2 b$ at a dose of $1.5 \mu \mathrm{g} / \mathrm{kg}$ body weight with RBV (15 mg/kg/day) for 48 weeks showed encouraging results in an open-labeled, uncontrolled pilot study with 62 children and adolescents (age 2-17 years). SVR was documented in $22(48 \%)$ of 46 patients with genotype 1 , in $13(100 \%)$ of 13 with genotype 2 or 3 , in one of two with genotype 4 , in $19(70 \%)$ of 27 children. ${ }^{55}$ Although Baker and colleagues reported a small study (10 children, age 11-18 years) evaluating the safety and efficacy of pegIFN $\alpha-2 b$ and RBV combination therapy for chronic HCV infection in the pediatric age group with a lower SVR of $30 \%$, the study included children with both treatment-naïve patients and those who failed to respond to a previous course of antiviral therapy. ${ }^{56}$ The rationale for adding RBV to pegIFN $\alpha-2$ a therapy is the higher SVR in adult studies using this combination. ${ }^{57}$ The recommended RBV doses and the duration of treatment depend on HCV genotypes and baseline viral loads, and can be further individualized on the basis of RVR and EVR. PegIFN $\alpha-2 a$ as monotherapy vs in combination with RBV in pediatric patients with $\mathrm{CHC}$ was the basis of the PEDS C trial, the first multicenter placebo-controlled trial for the treatment of $\mathrm{CHC}$ in children aged 5 years through 18 years. ${ }^{58}$ By 2008, there were two FDA-approved antiviral therapies for children: thrice weekly IFN plus RBV, indicated for children aged 3-18 years with $\mathrm{HCV}$ infection and once weekly pegIFN $\alpha-2 b$ plus RBV for children aged 5-18 years; both are given 48 weeks for children with genotype 1 and 4. Children with genotype 2 or 3 may require only 24 weeks of therapy like adults but the issue has not been well studied in children. ${ }^{58}$

\section{Adverse effects in HCV therapy in children and their management}

Although adverse effects and laboratory abnormalities related to treatments with standard IFN or pegIFN are similar including minor clinical signs such as fever, flu-like symptoms, headache, anorexia, neutropenia and more severe signs (21.4\%) such as depression (less common in children), irritability, alopecia, and the development of thyroid and liver autoantibodies and impairment of thyroid function, the weekly administration of pegIFN minimizes fever, anorexia, or flu-like symptoms. ${ }^{55,59,60}$ Severe neurotoxicity in the form of spastic diplegia has been sporadically reported in infants using IFN $\alpha$. This is so undesirable that that form of IFNo therapy has been avoided in infants younger than 1 year. In a recent study, five infants with hemangiomas developed a spastic diplegia during IFN-a therapy. The mechanisms of the neurotoxicity of IFN-a are not clear and spasticity appears late during the course of treatment, the cumulative dose and not the maximum daily dose may be an important factor. Interferon alpha-2a therapy in hemangiomas of infancy: spastic diplegia as a severe complication. ${ }^{61}$

The use of epoetin alfa and granulocyte colony-stimulating factor generally is not recommended or required for treating neutropenia and anemia, adverse effects from pegINF/RBV. Since these side effects are dose-dependent, dose reduction by $20 \%$ to $30 \%$ of pegIFN has been performed based on degrees of neutropenia in a pediatric study. ${ }^{55}$

Common side effects of RBV include nausea, skin rash, cough, and shortness of breath. The most common side effect is hemolytic anemia which is dose-dependent and occurs during the first four weeks of therapy. ${ }^{62}$ Although dose-dependent hemolytic anemia was observed, it did not require drug discontinuation in any of 61 treated children. ${ }^{63}$ The average decrease in hemoglobin is of 2 to $3 \mathrm{~g}$. The degree of anemia also determines the adjustment of RBV dosage during the course of treatment; however the dose reduction may affect the SVR. In addition to hemolytic anemia, RBV has teratogenic and embryotoxic effects in animal studies and should be a major concern when using it in individuals of child-bearing age including both female and male adolescents. ${ }^{64}$ The long-term side effects of RBV in children and adolescents are still unknown. Therefore educating parents and patients about the natural disease, the treatment course of $\mathrm{HCV}$ infection, adverse effects of the treatment is essential at each visit.

\section{Patient/family education and laboratory monitoring}

Teaching sessions can be performed to parents at the time the patients receiving their first doses with premedication regimen (acetaminophen and diphenhydramine) in the clinic including selecting and rotating injection sites, site preparation, delivering medications, time of administration (at bedtime), sharp disposal, and storage of medications. Sex education, nutritional assessment, and psychiatric 
screening should be addressed before the treatment and reinforced on follow-up visits.

There are specific advice following manufacturer guidelines on laboratory monitoring and dose adjustment for pegIFN and RBV. In general complete blood count, liver function test, thyroid function tests and also quantitative RT-PCR of HCV RNA should be monitored at four weeks, 12 weeks, six months (genotype 2 and 3 ) or one year (genotype 1 and 4) and six months after the end of therapy.

\section{New antiviral agents for pediatric use}

In developing newer or more effective therapies, careful attention should be paid to the unique physiology and psychological needs in pediatric population. Children generally have much lower viral loads and precirrhotic. The time elapsed from infection and diagnosis is shorter in most cases. Younger children also have been reported to clear the virus after acute $\mathrm{HCV}$ infection at a higher rate than older children and adults. ${ }^{63}$ At the same time caregivers with $\mathrm{CHC}$ are known to have great concern about their children's health condition and often seek many opinions for HCV therapy. ${ }^{48}$

The PEDS-C trial is an example of great effort from devoted and interested pediatric subspecialists who studied pharmacokinetics and efficacy of the potential medications, developed a safe protocol for $\mathrm{HCV}$ therapy in pediatric populations in 2000-2008 and concluded annual follow-ups and all ancillary studies in 2009. The trial was financially supported by both government and Industry and included a highly functional organization of pediatric subspecialists, research coordinators, and investigational pharmacists, working together with government and industry scientists. ${ }^{58}$

Safety assessments are required prior to using new agents in children. Currently there have been no pediatric trials of PIs, Nis, NNIs, TLR agonists, thymosin, histamine, antifibrotic agents alone or in combination with (peg)IFN and RBV therapy. The future use of these agents in children with $\mathrm{CHC}$ is probably in combination with pegIFN and RBV; attempts should be made to minimize pegIFN side effects, perhaps by shortening the duration of therapy and to improve the SVR in all patients as well as to treat nonresponders or cirrhotic patients. Among these new agents, telaprevir seems the most promising in a clinical trial in patients (age range $18-65$ years) with pegIFN and RBV. ${ }^{32}$ However druginduced rash occurred with the median time at 73 days (range 8-88 days) after the start of treatment and severe rash and pruritus were a common indication to discontinue telaprevir in 12 of 175 patients with all telaprevir-based regimens. ${ }^{65}$
Severe rash occurred in approximately $5 \%$ of patients treated with telaprevir. ${ }^{32}$ A good design for a pediatric trial might be a lead-in 60-day-period of telaprevir or placebo plus pegIFN/ RBV. As increased adverse effects with rash or anemia occur over the time of treatment (median time at 73 days), telaprevir would be likely tolerated in the first 60 days after the administration of this medication. Telaprevir could then be discontinued in those who do not respond or achieve viral response $\geq 2 \log _{10} \mathrm{IU} / \mathrm{mL}$ decline in HCV RNA from pretreatment baseline at 60 days of the treatment to avoid these side effects.

\section{Co-infection with HBV or HIV infection}

$\mathrm{HCV}$ increases mortality in hepatitis B virus- (HBV) or human immunodeficiency virus- (HIV) infected patients as they develop accelerated liver disease and consequently cirrhosis, liver failure, and hepatocellular carcinoma. ${ }^{66}$ Treatment for HCV infection in HIV-infected individuals includes with standard pegIFN/RBV or maintenance therapy with low-dose pegIFN, administered in an attempt to slow fibrosis progression. ${ }^{67}$ Response rates to $\mathrm{HCV}$ therapy are generally $10 \%-15 \%$ lower than in HCV monoinfection. The treatment of $\mathrm{HCV}$ is often recommended prior to highly active antiretroviral therapy (HAART) to avoid the issues of drug interactions on $\mathrm{HCV}$ therapy and the risk of HAART-related hepatotoxicity. Many vertically HIV-infected children however are started on HAART therapy very early on when HCV therapy is not available below the age of three years. ${ }^{68}$ The treatment in young infants coinfected with HIV and HCV should be focused on HAART therapy first since they may spontaneously clear $\mathrm{HCV}$ by age $2-3$ years and IFN $\alpha$ therapy could potentially cause neurologic side effects. It is also possible that combination therapy should be considered in younger children with CHC aged between 2-3 years, particularly in those with high $\mathrm{HCV}$ viral load. New therapies, including HCV PIs, Nis, and NNIs are in development and may give therapeutic options for HIV-HCV-coinfected children in the future. ${ }^{66}$

\section{Liver transplantation in children with CHC}

The outcomes of OLT are not favorable in adult patients with CHC. ${ }^{69,70}$ Data from the United States was based on retrospective assessment of all pediatric patients below the age of 17 years who have undergone liver transplant for management of HCV infection using the United Network for Organ Sharing OLT database. ${ }^{71}$ The patient and graft survival rates at five years after OLT in these young subjects 
were $71.6 \%$ and $55 \%$, respectively, comparable to reported rates in adult patients. Rates were considerably lower after re-transplantation (55.5\% and 33.8\%, respectively) with 34\% dying following initial transplantation or re-transplantation. More studies and observation are required to weigh risks and benefit of liver transplant and criteria for medical treatment of $\mathrm{HCV}$ in children with end-stage liver disease.

\section{Cost and financial burden}

The financial burden of HCV is undoubtedly high in both developed and developing countries, with projected medical costs of $\$ 10.7$ billion in adults from 2010 to 2019 and approximately $\$ 426$ million for the next 10 years. ${ }^{72-74}$ Jhaveri and colleagues have recently estimated the direct medical costs related to $\mathrm{HCV}$ in childhood projected for the next decade. These include US\$26 million for screening, \$117-206 million for monitoring, and \$56-104 million for treatment costs. ${ }^{72}$ The knowledge on global, regional, and national rates of morbidity and mortality associated with $\mathrm{HCV}$ infection based on prevalence, incidence, transmission and economics in each part of the world as well as a better understanding of the natural history of $\mathrm{HCV}$ infection are required in estimating the global burden of the disease associated with HCV infection in children.

\section{Prevention}

Currently, there is no effective way to prevent the transmission of HCV from mother to infant. It is not certain when during pregnancy and delivery $\mathrm{HCV}$ transmission occurs, however, one study suggested that $1 / 3$ to $1 / 2$ of infants acquiring $\mathrm{HCV}$ from their mothers were infected in utero. ${ }^{75}$ Although HCV RNA is detectable in maternal colostrum, viral transmission via breastfeeding has not been well documented. Inactivation of the virus by gastric acid and very low levels of virus in breast milk may explain this potential protective mechanism. The American Academy of Pediatrics and the American College of Obstetricians and Gynecologists support breastfeeding by mothers with HCV infection. ${ }^{76}$ At present neither elective Cesarean section nor avoidance of breastfeeding should be recommended to $\mathrm{HCV}$-infected women ${ }^{77}$ although scattered reports do show a higher risk of HCV transmission for infants whose mothers were HCV-RNA positive in breast milk. ${ }^{78}$ However, Mast and colleagues reported that membrane rupture $\geq 6$ hours and internal fetal monitoring were associated with increased rates of transmission of HCV from mother to infant, suggesting a possibility of reduction of transmission by modification of obstetric practices. ${ }^{79}$ An association of higher transmission rates with intrapartum exposure to virus-contaminated maternal blood was reported secondary to a perineal or vaginal laceration. ${ }^{80}$ There is definitely a role for public education about risk avoidance for high risk children and adolescents. Schwarz and colleagues recently reported that $19 \%$ of homeless caregivers were anti-HCV positive and no cases of $\mathrm{HCV}$ infection were found in their children, suggesting the importance of directing preventive education to the young. ${ }^{80}$ Unlike HIV infection, antiviral therapy is contraindicated in pregnant women and not available in young infants with $\mathrm{HCV}$ infection. Preventing maternal to fetal transmission in HCV infection is a very important research goal and will require a multidisciplinary approach.

\section{Vaccines}

$\mathrm{HCV}$ vaccines have been developed using structural protein E1 and E2, DNA, and viral vectors with the purpose of stimulating both a humoral and a cellular response. ${ }^{81}$ Development of an effective HCV vaccine has long been defined as a difficult challenge due to the considerable variability of this RNA virus. ${ }^{81}$ Convalescent humans and chimpanzees could be re-infected after re-exposure. Targets at E2 with hypervariable regions constantly change with an evolving quasispecies profile. ${ }^{81}$ A phase I study of vaccine using protein $\mathrm{E} 1$ resulted in a humoral and cellular response in healthy subjects. ${ }^{82}$ The induction and maintenance of strong helper and cytotoxic T-cell immune responses against multiple viral epitopes are necessary for viral protection as seen in chronic infection of chimpanzees receiving prophylactic vaccines. Cellular responses may be enhanced by rapid induction of cross-neutralizing antibodies via a multispecific B-cell response. CHC carriers are known to have impaired immune function and restoring T-cell functions is expected to enhance the efficacy of therapeutic vaccine in current and future clinical trials. ${ }^{83}$

\section{Conclusion}

$\mathrm{CHC}$ has become a global health concern and will leads to increasingly financial burden. Maternal to fetal transmission becomes the most common route of $\mathrm{HCV}$ acquisition in pediatric population. The majority of these children with $\mathrm{CHC}$ do well, but their liver disease course could eventually transform into chronic liver disease and its complication in early adulthood given the lengthy duration of HCV infection since birth. Standard combination therapy with pegIFN and RBV seems to be promising in the pediatric population. PegIFN, despite all its side effects, will remain the key element of $\mathrm{HCV}$ treatment. RBV is essential as a 
combination therapy with pegIFN and may be replaced when safer or more potent drugs are available. A shorter, safer, and more effective therapy or probably a combination of other potent antiviral agents preventing the development of resistant viral strains is the future ideal therapy for HCV infection for both children and adults. Although there is the hope of spontaneous viral clearance in children aged less than 3 years, the majority of $\mathrm{HCV}$-infected children will have $\mathrm{CHC}$. With that regard, the use of combination therapy of pegIFN/RBV in young children with HCV needs urgent evaluation along with a critical review of the adverse side effects, risks/benefit ratio of the therapy, and socioeconomic and ethical considerations. A better response to HAART therapy among vertically HIV-infected infants who begin immediate treatment in recent studies or prenatal therapy in pregnant HIV-infected mothers should be a good model for study of treatment of vertically HCV-infected children.

\section{Disclosures}

The authors report no conflicts of interest in this work.

\section{References}

1. Wasley A, Alter MJ. Epidemiology of hepatitis C: geographic differences and temporal trends. Semin Liver Dis. 2000;20:1-16.

2. Roudot-Thoraval F, Bastie A, Pawlotsky JM, Dhumeaux D. Epidemiological factors affecting the severity of hepatitis $\mathrm{C}$ virus-related liver disease: a French survey of 6,664 patients. The Study Group for the Prevalence and the Epidemiology of Hepatitis C Virus. Hepatology. 1997;26:485-490.

3. Gonzalez-Peralta RP, Langham MR Jr, Andres JM, et al. Hepatocellular carcinoma in 2 young adolescents with chronic hepatitis C. J Pediatr Gastroenterol Nutr. 2009;48:630-635.

4. Layden TJ, Lam NP, Wiley TE. Hepatitis C viral dynamics. Clin Liver Dis. 1999;3:793-810.

5. Luban NL, Colvin CA, Mohan P, Alter HJ. The epidemiology of transfusion-associated hepatitis $\mathrm{C}$ in a children's hospital. Transfusion. 2007; 47:615-620.

6. Lam NP. Hepatitis C: natural history, diagnosis, and management. Am J Health Syst Pharm. 1999;56:961-973; quiz, 974-975.

7. Nelson DR, Davis GL, Jacobson I, et al. Hepatitis C virus: a critical appraisal of approaches to therapy. Clin Gastroenterol Hepatol. 2009;7:397-414; quiz, 366.

8. National Institutes of Health. National Institutes of Health Consensus Development Conference Statement: Management of hepatitis C: 2002 - June 10-12, 2002. Hepatology. 2002;36:S3-S20.

9. Masci P, Bukowski RM, Patten PA, Osborn BL, Borden EC. New and modified interferon alfas: preclinical and clinical data. Curr Oncol Rep. 2003;5:108-113.

10. Shiffman ML. Chronic hepatitis C: treatment of pegylated interferon/ ribavirin nonresponders. Curr Gastroenterol Rep. 2006;8:46-52.

11. Leung NW. Management of viral hepatitis C. J Gastroenterol Hepatol. 2002;17(Suppl):S146-S154.

12. Martin P, Jensen DM. Ribavirin in the treatment of chronic hepatitis $\mathrm{C}$. J Gastroenterol Hepatol. 2008;23:844-855.

13. Querenghi F, Yu Q, Billaud G, Maertens G, Trepo C, Zoulim F. Evolution of hepatitis $\mathrm{C}$ virus genome in chronically infected patients receiving ribavirin monotherapy. J Viral Hepat. 2001;8:120-131.
14. Poynard T, Marcellin P, Lee SS, et al. Randomised trial of interferon alpha2b plus ribavirin for 48 weeks or for 24 weeks vs interferon alpha $2 \mathrm{~b}$ plus placebo for 48 weeks for treatment of chronic infection with hepatitis $\mathrm{C}$ virus. International Hepatitis Interventional Therapy Group (IHIT). Lancet. 1998;352:1426-1432.

15. McHutchison JG, Gordon SC, Schiff ER, et al. Interferon alfa-2b alone or in combination with ribavirin as initial treatment for chronic hepatitis C. Hepatitis Interventional Therapy Group. $N$ Engl J Med. 1998;339:1485-1492.

16. Reichard O, Norkrans G, Fryden A, Braconier JH, Sonnerborg A, Weiland O. Randomised, double-blind, placebo-controlled trial of interferon alpha-2b with and without ribavirin for chronic hepatitis $\mathrm{C}$. The Swedish Study Group. Lancet. 1998;351:83-87.

17. Teuber G, Berg T, Hoffmann RM, et al. Retreatment with interferonalpha and ribavirin in primary interferon-alpha non-responders with chronic hepatitis C. Digestion. 2000;61:90-97.

18. Nishiguchi S, Kuroki T, Nakatani S, et al. Randomised trial of effects of interferon-alpha on incidence of hepatocellular carcinoma in chronic active hepatitis C with cirrhosis. Lancet. 1995;346:1051-1055.

19. Nishiguchi $S$, Shiomi S, Nakatani S, et al. Prevention of hepatocellular carcinoma in patients with chronic active hepatitis $\mathrm{C}$ and cirrhosis. Lancet. 2001;357:196-197.

20. Deutsch M, Hadziyannis SJ. Old and emerging therapies in chronic hepatitis C: an update. J Viral Hepat. 2008;15:2-11.

21. Glue P, Fang JW, Rouzier-Panis R, et al. Pegylated interferon-alpha2b: pharmacokinetics, pharmacodynamics, safety, and preliminary efficacy data. Hepatitis C Intervention Therapy Group. Clin Pharmacol Ther. 2000;68:556-567.

22. Yenice N, Mehtap O, Gumrah M, Arican N. The efficacy of pegylated interferon alpha $2 \mathrm{a}$ or $2 \mathrm{~b}$ plus ribavirin in chronic hepatitis $\mathrm{C}$ patients. Turk J Gastroenterol. 2006;17:94-98.

23. Dalgard O, Bjoro K, Ring-Larsen H, et al. Pegylated interferon alfa and ribavirin for 14 vs 24 weeks in patients with hepatitis $C$ virus genotype 2 or 3 and rapid virological response. Hepatology. 2008;47:35-42.

24. Foster GR. Hepatitis $\mathrm{C}$ virus infection: quality of life and side effects of treatment. J Hepatol. 1999;31(Suppl 1):250-254.

25. Trépo C, Marion-Audibert AM, Samuel D, Guyader D, Fontanges T. [Maintenance therapy for chronic hepatitis C]. Gastroenterol Clin Biol. 2007;31:(8-9 Pt 3):4S29-S33.

26. Osborn BL, Olsen HS, Nardelli B, et al. Pharmacokinetic and pharmacodynamic studies of a human serum albumin-interferon-alpha fusion protein in cynomolgus monkeys. J Pharmacol Exp Ther. 2002;303:540-548.

27. Melian EB, Plosker GL. Interferon alfacon-1: a review of its pharmacology and therapeutic efficacy in the treatment of chronic hepatitis C. Drugs. 2001;61:1661-1691.

28. Moskovitz DN, Manoharan P, Heathcote EJ. High dose consensus interferon in nonresponders to interferon alpha- $2 \mathrm{~b}$ and ribavirin with chronic hepatitis C. Can J Gastroenterol. 2003;17:479-482.

29. Heathcote EJ, Keeffe EB, Lee SS, et al. Re-treatment of chronic hepatitis C with consensus interferon. Hepatology. 1998;27:1136-1143.

30. Bacon BR, Shiffman ML, Mendes F, et al. Retreating chronic hepatitis C with daily interferon alfacon-1/ribavirin after nonresponse to pegylated interferon/ribavirin: DIRECT results. Hepatology. 2009;49:1838-1846.

31. Brown NA. Progress towards improving antiviral therapy for hepatitis C with hepatitis $C$ virus polymerase inhibitors. Part I: Nucleoside analogues. Expert Opin Investig Drugs. 2009;18(6):709-725.

32. Hezode C, Forestier N, Dusheiko G, et al. Telaprevir and peginterferon with or without ribavirin for chronic HCV infection. $N$ Engl $J$ Med. 2009;360:1839-1850.

33. Schiff ER. Emerging strategies for pegylated interferon combination therapy. Nat Clin Pract Gastroenterol Hepatol. 2007;4(Suppl 1):S17-S21.

34. Soler M, McHutchison JG, Kwoh TJ, Dorr FA, Pawlotsky JM. Virological effects of ISIS 14803, an antisense oligonucleotide inhibitor of hepatitis $\mathrm{C}$ virus (HCV) internal ribosome entry site (IRES), on HCV IRES in chronic hepatitis $\mathrm{C}$ patients and examination of the potential role of primary and secondary $\mathrm{HCV}$ resistance in the outcome of treatment. Antivir Ther. 2004;9:953-968. 
35. Horsmans Y, Berg T, Desager JP, et al. Isatoribine, an agonist of TLR7, reduces plasma virus concentration in chronic hepatitis $\mathrm{C}$ infection. Hepatology. 2005;42:724-731.

36. Iken K, Huang L, Bekele H, Schmidt EV, Koziel MJ. Apoptosis of activated CD4+ and CD8+ T cells is enhanced by co-culture with hepatocytes expressing hepatitis $\mathrm{C}$ virus (HCV) structural proteins through FasL induction. Virology. 2006;346:363-372.

37. Croquet V, Moal F, Veal N, et al. Hemodynamic and antifibrotic effects of losartan in rats with liver fibrosis and/or portal hypertension. J Hepatol. 2002;37:773-780.

38. Pockros PJ, Schiff ER, Shiffman ML, et al. Oral IDN-6556, an antiapoptotic caspase inhibitor, may lower aminotransferase activity in patients with chronic hepatitis C. Hepatology. 2007;46:324-329.

39. Berenguer M, Prieto M, Palau A, et al. Severe recurrent hepatitis C after liver retransplantation for hepatitis $\mathrm{C}$ virus-related graft cirrhosis. Liver Transpl. 2003;9:228-235.

40. Goodman ZD, Makhlouf HR, Liu L, et al. Pathology of chronic hepatitis $\mathrm{C}$ in children: liver biopsy findings in the Peds-C Trial Hepatology. 2008;47:836-843.

41. Roberts EA, Yeung L. Maternal-infant transmission of hepatitis C virus infection. Hepatology. 2002;36:S106-S113.

42. Airoldi J, Berghella V. Hepatitis C and pregnancy. Obstet Gynecol Surv. 2006;61:666-672.

43. Bortolotti F, Verucchi G, Camma C, et al. Long-term course of chronic hepatitis $\mathrm{C}$ in children: from viral clearance to end-stage liver disease. Gastroenterology. 2008;134:1900-1907.

44. Chen ST, Ni YH, Chen PJ, et al. Low viraemia at enrollment in children with chronic hepatitis $\mathrm{C}$ favours spontaneous viral clearance. $J$ Viral Hepat. 2009;Apr 22. [Epub ahead of print].

45. Garcia-Monzon C, Jara P, Fernandez-Bermejo M, et al. Chronic hepatitis $\mathrm{C}$ in children: a clinical and immunohistochemical comparative study with adult patients. Hepatology. 1998;28:1696-1701.

46. Locasciulli A, Testa M, Pontisso P, et al. Prevalence and natural history of hepatitis $\mathrm{C}$ infection in patients cured of childhood leukemia. Blood. 1997;90:4628-4633.

47. Yeung LT, King SM, Roberts EA. Mother-to-infant transmission of hepatitis C virus. Hepatology. 2001;34:223-229.

48. Rodrigue JR, Balistreri W, Haber B, et al. Impact of hepatitis $\mathrm{C}$ virus infection on children and their caregivers: quality of life, cognitive, and emotional outcomes. J Pediatr Gastroenterol Nutr. 2009;48: 341-347.

49. European Paediatric Hepatitis C Virus Network. Three broad modalities in the natural history of vertically acquired hepatitis $\mathrm{C}$ virus infection. Clin Infect Dis. 2005;41:45-51.

50. Mohan P, Colvin C, Glymph C, et al. Clinical spectrum and histopathologic features of chronic hepatitis $\mathrm{C}$ infection in children. $J$ Pediatr. 2007; 150:168,74, 174.e1.

51. American Academy of Pediatrics. In: Pickering LK, Baker CJ, Long SS, McMillan JA, editors. Red Book: 2006 Report of the Committee on Infectious Diseases. 27th ed. Elk Grove Village, IL: American Academy of Pediatrics; 2006. p. 356.

52. Jacobson KR, Murray K, Zellos A, Schwarz KB. An analysis of published trials of interferon monotherapy in children with chronic hepatitis C. J Pediatr Gastroenterol Nutr. 2002;34:52-58.

53. Wirth S, Lang T, Gehring S, Gerner P. Recombinant alfa-interferon plus ribavirin therapy in children and adolescents with chronic hepatitis $\mathrm{C}$. Hepatology. 2002;36:1280-1284.

54. Schwarz KB, Mohan P, Narkewicz MR, et al. Safety, efficacy and pharmacokinetics of peginterferon alpha2a $(40 \mathrm{kd})$ in children with chronic hepatitis C. J Pediatr Gastroenterol Nutr. 2006;43: 499-505.

55. Wirth S, Pieper-Boustani H, Lang T, et al. Peginterferon alfa-2b plus ribavirin treatment in children and adolescents with chronic hepatitis $\mathrm{C}$. Hepatology. 2005;41:1013-1018.

56. Baker RD, Dee D, Baker SS. Response to pegylated interferon alpha-2b and ribavirin in children with chronic hepatitis C. J Clin Gastroenterol. 2007;41:111-114.
57. Kjaergard LL, Krogsgaard K, Gluud C. Interferon alfa with or without ribavirin for chronic hepatitis $\mathrm{C}$ : systematic review of randomised trials. BMJ. 2001;323:1151-1155.

58. Murray KF, Rodrigue JR, Gonzalez-Peralta RP, et al. Design of the PEDS-C trial: pegylated interferon $+/-$ ribavirin for children with chronic hepatitis C viral infection. Clin Trials. 2007;4:661-673.

59. Gehring S, Kullmer U, Koeppelmann S, Gerner P, Wintermeyer P, Wirth S. Prevalence of autoantibodies and the risk of autoimmune thyroid disease in children with chronic hepatitis $\mathrm{C}$ virus infection treated with interferon-alpha. World J Gastroenterol. 2006;12: 5787-5792.

60. Pensati P, Iorio R, Botta S, et al. Low virological response to interferon in children with chronic hepatitis C. J Hepatol. 1999;31:604-611.

61. Wörle H, Maass E, Köhler B, Treuner J. Interferon alpha-2a therapy in haemangiomas of infancy: spastic diplegia as a severe complication. Eur J Pediatr. 1999;158:344.

62. Lai MY, Kao JH, Yang PM, et al. Long-term efficacy of ribavirin plus interferon alfa in the treatment of chronic hepatitis C. Gastroenterology. 1996;111:1307-1312.

63. Jonas MM. Children with hepatitis C. Hepatology. 2002;36:S173-S178.

64. Krilov LR. Safety issues related to the administration of ribavirin. Pediatr Infect Dis J. 2002;21:479-481.

65. McHutchison JG, Everson GT, Gordon SC, et al. Telaprevir with peginterferon and ribavirin for chronic HCV genotype 1 infection. N Engl J Med. 2009;360:1827-1838.

66. Matthews GV, Dore GJ. HIV and hepatitis C coinfection. J Gastroenterol Hepatol. 2008;23:1000-1008.

67. Kadam JS, Talal AH. Changing treatment paradigms: hepatitis C virus in HIV-infected patients. AIDS Patient Care STDS. 2007;21:154-168.

68. Beneri CA, Nachman S. To treat or not to treat? No longer a question. Future Microbiol. 2009;4:391-395.

69. Testa G, Crippin JS, Netto GJ, et al. Liver transplantation for hepatitis C: recurrence and disease progression in 300 patients. Liver Transpl. 2000;6:553-561.

70. Ghobrial RM, Steadman R, Gornbein J, et al. A 10-year experience of liver transplantation for hepatitis $\mathrm{C}$ : analysis of factors determining outcome in over 500 patients. Ann Surg. 2001;234:384-393; discussion 393-394.

71. Barshes NR, Udell IW, Lee TC, et al. The natural history of hepatitis $\mathrm{C}$ virus in pediatric liver transplant recipients. Liver Transpl. 2006;12:1119-1123.

72. Jhaveri R, Grant W, Kauf TL, McHutchison J. The burden of hepatitis $\mathrm{C}$ virus infection in children: estimated direct medical costs over a 10-year period. J Pediatr. 2006;148:353-358.

73. Lavanchy D. The global burden of hepatitis C. Liver Int. 2009; 29(Suppl 1):74-81.

74. Wong JB, McQuillan GM, McHutchison JG, Poynard T. Estimating future hepatitis $\mathrm{C}$ morbidity, mortality, and costs in the United States. Am J Public Health. 2000;90:1562-1569.

75. Mok J, Pembrey L, Tovo PA, Newell ML, European Paediatric Hepatitis C Virus Network. When does mother to child transmission of hepatitis C virus occur? Arch Dis Child Fetal Neonatal Ed. 2005;90: F156-F160.

76. American Academy of Pediatrics. In: Pickering LK, Baker CJ, Long SS, McMillan JA, editors. Red Book: 2006 Report of the Committee on Infectious Diseases. 27th ed. Elk Grove Village, IL: American Academy of Pediatrics; 2006. pp. 326-361.

77. Pembrey L, Newell ML, Tovo PA, EPHN Collaborators. The management of HCV infected pregnant women and their children. European Paediatric HCV network. J Hepatol. 2005;43:515-525.

78. Ruiz-Extremera A, Salmeron J, Torres C, et al. Follow-up of transmission of hepatitis $\mathrm{C}$ to babies of human immunodeficiency virusnegative women: the role of breast-feeding in transmission. Pediatr Infect Dis J. 2000;19:511-516.

79. Mast EE, Alter MJ, Margolis HS. Strategies to prevent and control hepatitis $\mathrm{B}$ and $\mathrm{C}$ virus infections: a global perspective. Vaccine. $1999 ; 17: 1730-1733$. 
80. Steininger C, Kundi M, Jatzko G, Kiss H, Lischka A, Holzmann H. Increased risk of mother-to-infant transmission of hepatitis $\mathrm{C}$ virus by intrapartum infantile exposure to maternal blood. J Infect Dis. 2003;187:345-351.

81. Leroux-Roels G. Development of prophylactic and therapeutic vaccines against hepatitis C virus. Expert Rev Vaccines. 2005;4:351-371.
82. Leroux-Roels G, Depla E, Hulstaert F, et al. A candidate vaccine based on the hepatitis $\mathrm{CE}$ 1 protein: tolerability and immunogenicity in healthy volunteers. Vaccine. 2004;22:3080-3086.

83. Stoll-Keller F, Barth H, Fafi-Kremer S, Zeisel MB, Baumert TF. Development of hepatitis $C$ virus vaccines: challenges and progress. Expert Rev Vaccines. 2009;8:333-345.

\section{Publish your work in this journal}

Therapeutics and Clinical Risk Management is an international, peerreviewed journal of clinical therapeutics and risk management, focusing on concise rapid reporting of clinical studies in all therapeutic areas, outcomes, safety, and programs for the effective, safe, and sustained use of medicines. This journal is indexed on PubMed Central, CAS,
EMBase, Scopus and the Elsevier Bibliographic databases. The manuscript management system is completely online and includes a very quick and fair peer-review system, which is all easy to use. Visit http://www.dovepress.com/testimonials.php to read real quotes from published authors.

Submit your manuscript here: http://www.dovepress.com/therapeutics-and-clinical-risk-management-journal 